\title{
SEBAB DAN AKIBAT STRES, DEPRESI DAN KECEMASAN SERTA PENANGGULANGANNYA
}

\section{Jamil}

STIT Al Amin Banten

jamil80@gmail.com

\begin{abstract}
:
Psychologically, humans often suffer from various disorders and mental illnesses, such as stress, depression, anxiety, envy, jealousy, sorrow unreasonable, arrogant and many others are. Challenges and struggles of life as well as moral and ethical values change, at certain conditions can lead to tension stress. Stress is part of life that cannot be avoided. Therefore, what we have to do is arrange life so that stress does not cause a reaction, such as physical or psychological complaints. This is called distress.
\end{abstract}

Keywords: Mental Ilnesses, Moral and Ethical Value, Arrange Stress. 


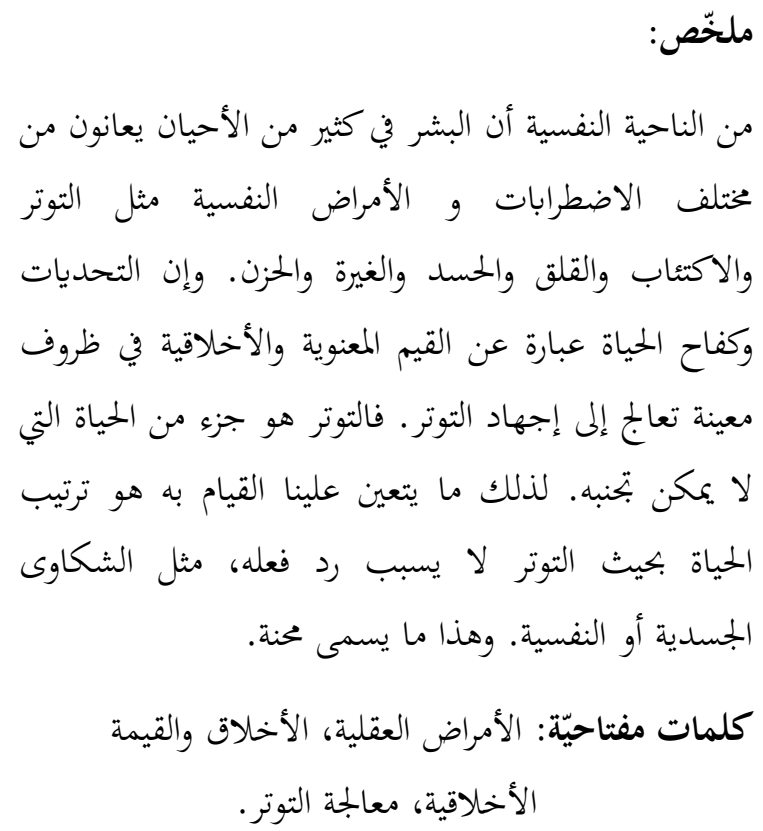

$\mathrm{M}$

anusia adalah makhluk paling mulia dan unik dibandingkan dengan ciptaan Tuhan lainnya. Oleh karena manusia dianugerahi berbagai potensi yaitu berupa jiwa, akal, jasad dan ruh. Keempat aspek tersebut saling mempengaruhi satu sama lainnya atau dengan istilah lain manusia itu memiliki sisi luar dan sisi dalam. Yang menjadi persoalan di bidang psikologi adalah lebih menitikberatkan pada aspek sisi dalam atau jiwa. Kesehatan mental yang merupakan salah satu sub disiplin psikologi lebih mengkhususkan kajiannya terhadap kesehatan mental jiwa.

Wacana tentang menyangkut stres, depresi dan cemas belum banyak dikaji, namun dalam perkembangannya, sebenarnya pembahasan ini ada yang mirip tetapi berbeda pembahasan. Namun penulis masih menganggap penting kajian ini dengan melihat aspek-aspek lain yang berbeda, yakni nuansa keagamaan Islam. Hal ini penting karena ternyata dalam teks-teks suci keagamaan banyak dijumpai petunjuk menanggulangi persoalan kejiwaan. Maka dalam rangka mengkonstruksi dan mendeskripsikan menyangkut 
stres, depresi dan cemas, maka metode yang dipakai dalam hal ini adalah 'teknik analisis'1 dan pemaparan 'argumentatif'.'

Tujuan yang ingin dicapai dan manfaat yang diharapkan dalam pembahasan ini adalah untuk mengetahui sebenarnya bagaimana posisi stres, depresi, dan cemas dalam kehidupan manusia yang dihubungkan dengan pendidikan. Tulisan ini diharapkan menjadi suatu bahan informasi dan masukan bagi khazanah pengembangan keilmuan, khususnya dalam bidang pemikiran modern Islam.

\section{A. Stres, Depresi, dan Cemas}

\section{Stres}

Istilah stress dan depresi seringkali tidak dapat dipisahkan satu dengan lainnya. Setiap permasalahan kehidupan yang menimpa pada diri seseorang (disebut Stresor Psikososial) dapat mengakibatkan gangguan fungsi organ tubuh. Reaksi tubuh (fisik) ini dinamakan stres, dan memaksa fungsi organ-organ tubuh itu sampai terganggu dinamakan Distress. Secara bahasa stres berarti tekanan dalam hal ini mempengaruhi kejiwaan.

Menurut Hans Sely, seorang ahli fisiologi dan tokoh di bidang stres yang terkemuka dari Universitas Montreal, merumuskan bahwa stres adalah tanggapan tubuh yang sifatnya non-spesifik terhadap tuntutan atasnya. Bilamana tuntutan terhadap tubuh itu berlebihan, maka

1 Analisis secara terminologi adalah penyelidikan terhadap suatu peristiwa, karangan, perbuatan dan sebagainya. Diartikan juga sebagai penguraian suatu pokok atas berbagai bagiannya dan penelaahan bagian-bagian sendiri, serta hubungan antara bagianbagian untuk memperoleh pengertian yang tepat dan pemahaman arti keseluruhan. Lihat Departemen Pendidikan dan Kebudayaan RI; Kamus Besar Bahasa Indonesia, (Jakarta: Balai Pustaka, t.th.), cet. II, h. 12. Lihat Tim Penyusun Ensiklopedia, Ensiklopedia Nasional Indonesia, (Jakarta: PT. Cipta Abadi, 1984), cet. II, Jilid II, h. 19. Lihat juga John Echols dan Hassan Syadily, Kamus InggrisIndonesia, (Jakarta: PT. Gramedia, 1976), cet. XIX, h. 22.

2 Argumentatif artinya usaha peneliti dalam mengarahkan ide-idenya dalam merekonstruksi masa lampau didasarkan atas bukti-bukti terseleksi, lengkap, detail, dan fakta akurat. Lihat Hasan Usman, Metode Penelitian Sejarah, (Jakarta: Departemen Agama, 1986), h. 171 . 
dinamakan distres. Tubuh akan berusaha menyelaraskan rangsangan atau stres itu dalam bentuk penyesuaian diri. Dalam banyak hal manusia cukup cepat untuk pulih kembali dari pengaruh stres. Manusia mempunyai suplai yang baik dan energi penyesuaian diri untuk dipakai dan diisi kembali. ${ }^{3}$

Stres adalah tanggapan atau reaksi tubuh terhadap berbagai tuntutan atau beban atasnya yang bersifat nonspesifik. Namun, di samping itu stres dapat juga merupakan faktor pencetus, penyebab sekaligus akibat dari suatu gangguan atau penyakit. Faktor psikososial cukup berarti bagi terjadinya stres pada seseorang. Manakala tuntutan pada seseorang melampaui kemampuannya, maka keadaan demikian disebut stres. Stres dalam kehidupan adalah suatu hal yang tidak dapat dihindari. Masalahnya adalah bagaimana manusia hidup dengan stres tanpa harus mengalami distres.

Sedangkan depresi adalah reaksi kejiwaan seseorang terhadap stressor yang dialaminya. Reaksi kejiwaan lainnya yang erat hubungannya dengan stres adalah kecemasan.

Kecemasan dan depresi merupakan dua jenis gangguan kejiwaan yang satu dengan lainnya saling berkaitan. Seseorang yang mengalami depresi seringkali ada komponen ansietasnya, demikian pula sebaliknya. Manifestasi depresi tidak selalu dalam bentuk keluhankeluhan kejiwaan, tetapi juga bisa dalam bentuk keluhankeluhan fisik atau sering disebut depresi terselubung, artinya keluhan-keluhan fisik yang latar belakangnya adalah depresi.

a. Stresor Psikososial

Stresor Psikososial adalah setiap keadaan yang menyebabkan perubahan dalam kehidupan seseorang (anak-anak, remaja, dan dewasa); sehingga orang itu terpaksa mengadakan adaptasi atau menanggulangi stressor yang timbul. Namun tidak semua orang mampu menanggulanginya, sehingga timbul keluhankeluhan kejiwaan, antara lain depresi.

3 Dadang Hawari, Al-Quraan Ilmu Kedokteran Jiwa dan Kesehatan Jiwa, (Jakarta: PT. Dana Bakti Primayasa, 1996), h. 4445.

126| Jurnal a l-Amin, Volume 3, No 1, 2015 M/1436 H 
Menurut Dadang Hawari, pada umumnya stresor psikososial, dapat digolongkan sebagai berikut: ${ }^{4}$

1) Perkawinan; perkawinan yang merupakan sumber stres ialah yang tidak harmonis, misalnya: pertengkaran, ketidaksetiaan, perceraian, kematian salah satu pasangan dan lain sebagainya. Stresor perkawinan ini dapat menyebabkan sesorang jatuh dalam depresi dan kecemasan.

2) Problem orang tua; permasalahan yang dihadapi orang tua, misalnya tidak punya anak, kebanyakan anak, kenakalan anak, anak sakit, hubungan yang tidak baik dengan mertua, ipar, besan dan lain-lain. Permasalahan tersebut merupakan sumber stres dan pada gilirannya yang bersangkutan jatuh dalam depresi dan cemas.

3) Hubungan interpersonal; gangguan ini dapat berupa hubungan dengan kawan dekat yang mengalami konflik, konflik dengan kekasih, antara atasan dan bawahan, dan lain sebagainya. Hal ini pun menjadi sumber stres yang pada akhirnya mengalami depresi dan cemas.

4) Pekerjaan; banyak orang menderita depresi dan kecemasan karena masalah pekerjaan, misalnya pekerjaan terlalu banyak, pekerjaan tidak cocok, mutasi jabatan, pensiun, kehilangan pekerjaan (PHK), dan lain-lain.

5) Lingkungan hidup; kondisi lingkungan yang buruk besar pengaruhnya terhadap kesehatan seseorang, misalnya soal perumahan, pindah tempat tinggal, penggusuran, lingkungan yang tidak aman dan lain sebagainya. Dengan terganggunya lingkungan rasa aman dan tenteram akan semakin jauh, sehingga tidak jarang seseorang jatuh dalam depresi dan kecemasan.

6) Keuangan; kondisi keuangan yang tidak sehat, misalnya pendapatan jauh lebih rendah daripada pengeluaran, terlibat hutang, bangkrut, soal warisan dan sebagainya. Problem keuangan ini

4 Dadang Hawari, Al-Qur'an Ilmu Kedokteran Jiwa dan Kesehatan Jiwa, h. 4647. 
amat berpengaruh pada kesehatan jiwa seseorang dan seringkali menjadi faktor yang membuat seseorang menjadi stres, depresi dan cemas.

7) Hukum; keterlibatan sesorang dalam masalah hukum dapat merupakan sumber stres pula misalnya: tuntutan hukum pengadilan, penjara dan lain sebagainya. Stres dalam hal ini dapat menyebabkan seseorang terkena depresi dan kecemasan.

8) Perkembangan; yang menjadi permasalahan dalam perkembangan di sini adalah baik fisik maupun mental, misalnya: masa remaja, dewasa, menopause, usia lanjut dan lain-lain.

9) Penyakit fisik/cedera; misalnya: kecelakaan, operasi/pembedahan aborsi dan lain sebagainya. Dalam hal penyakit yang banyak menimbulkan depresi dan kecemasan adalah penyakit kronis, jantung, kanker, dan sebangsanya.

10) Faktor keluarga; yang dimaksud di sini adalah faktor stres yang dialami anak dan remaja yang disebabkan karena sikap orang tua, misalnya: hubungan kedua orang tua yang dingin, atau penuh ketegangan, atau acuh tak acuh, kedua orang tua jarang di rumah, komunikasi antara orang tua dengan anak tidak baik dan lain sebagainya.

11) Dalam salah satu penelitian lainnya disebutkan bahwa kini di Amerika Serikat terdapat enam penyebab kematian utama yang erat hubungannya dengan stres dan kecemasan, berturut-turut yaitu: 1) penyakit jantung koroner, 2) Kanker, 3) Paruparu, 4) Kecelakaan, 5) Pengerasan hati, 6) Bunuh diri.

12) Tahapan-tahapan stres dikemukakan oleh Dr. Robert J. Van Amberg, sebagai berikut, mulai dari stres tingkat pertama yang paling rendah sampai pada stres tingkat keenam, merupakan tahapan puncak yang merupakan keadaan gawat darurat yang tidak jarang penderita dalam tahap ini dibawa ke ICCU.

\section{Depresi}


Salah satu bentuk stres yang dapat menimbulkan gangguan kejiwaan kecuali kecemasan (ansietas) adalah juga yang dinamakan depresi.

Depresi adalah salah satu bentuk gangguan kejiwaan pada alam perasaan, yang ditandai dengan kemurungan, kelesuan, ketiadaan gairah hidup, perasaan tidak berguna, putus asa, dan lain sebagainya. Menurut Prof Dr. Mustafa Fahmi, orang yang terserang gejala depresi mengalami rasa cemas, tidak percaya diri, menyendiri dan sempit lapangan perhatian. ${ }^{5}$

Depresi merupakan masalah kesehatan jiwa yang utama dewasa ini. Hal ini amat penting karena orang dengan depresi akan menurun produktivitasnya dan akibatnya amat buruk bagi suatu masyarakat atau negara yang sedang membangun. Depresi adalah penyebab utama tindakan bunuh diri, dan tindakan ini menduduki urutan ke-6 dari penyebab kematian di Amerika Serikat. ${ }^{6}$

Dari hasil penelitian yang dilakukan oleh Keilholz dan Poldinger menunjukkan bahwa $10 \%$ dari pasien yang berobat pada dokter adalah pasien depresi, dan separuhnya merupakan depresi terselubung. Penelitian lain yang dilakukan Klinik Psikiatri Universitas Basle terdapat angka $18 \%$. Sehubungan dengan hal tersebut, Sartorius memperkirakan 100 juta penduduk dunia mengalami depresi. Angka ini semakin bertambah untuk masa mendatang yang disebabkan antara lain: usia harapan hidup semakin bertambah, stresor sosial semakin berat, berbagai penyakit kronik semakin bertambah, kehidupan beragama semakin ditinggalkan (masyarakat sekuler).

Adapun ciri-ciri kepribadian depresif sebagai berikut, yaitu pemurung, sukar untuk senang, atau sukar untuk bahagia, pesimis menghadapi masa depan, memandang diri rendah, mudah merasa bersalah, mudah mengalah, enggan bicara, mudah merasa haru, sedih dan menangis, gerakan lamban, lemah lesu, seringkali mengeluh sakit, mudah tegang, agitatif, gelisah, serba cemas, mudah

5 Musthafa Fahmi, Kesehatan Jiwa Dalam Keluarga Sekolah dan Masyarakat, alih bahasa oleh Zakiah Daradjat (Jakarta: Bulan Bintang, 1977), Jilid 3, h. 35.

6 Dadang Hawari, Al-Qurian Ilmu Kedokteran Jiwa dan Kesehatan Jiwa, h. 56. 
tersinggung, merasa tidak mampu, merasa tidak berguna dan lain sebagainya. ${ }^{7}$

\section{Cemas}

Kecemasan adalah manifestasi dari berbagai proses emosi yang bercampur, yang terjadi ketika orang sedang mengalami tekanan perasaan (frustrasi) dan pertentangan batin. ${ }^{8}$ Kecemasan mempunyai segi yang disadari seperti rasa takut, terkejut, tidak berdaya, rasa berdosa atau bersalah, terancam dan sebagainya. Juga ada segi-segi yang terjadi di luar kesadaran dan tidak bisa menghindari perasaan yang tidak menyenangkan tersebut. Rasa cemas ada dalam semua gangguan dan penyakit jiwa. Kecemasan, menurut Ahmad Mubarok, merupakan salah satu gangguan kejiwaan yang diderita oleh manusia modern yang bersumber dari hilangnya makna hidup (the meaning of life). ${ }^{9}$

Gejala kecemasan baik yang sifatnya akut maupun kronik merupakan komponen utama bagi hampir semua gangguan psikiatrik. Sebagian dan komponen kecemasan itu menjelma dalam bentuk gangguan panik. Bahkan karena begitu memuncaknya kecemasan pada diri seseorang, seringkali dirasakan sebagai suatu serangan panik.

Bila diperhatikan dalam kehidupan ini ada orang yang takut secara umum, misalnya takut mencoba menghadang sesuatu, takut bertemu dengan orang yang belum dikenalnya, takut berbicara di depan orang banyak, dan takut menghadapi ujian. Dia ragu akan kemampuannya dalam setiap langkah yang akan ditempuhnya. Kalau diteliti riwayat kehidupan orang tersebut akan ditemukan bahwa dulu orang dewasa selalu memperingatkan dan mencelanya, atau cara lain yang menyebabkan kecemasan. ${ }^{10}$

7 Dadang Hawari, Al-Qur'an Ilmu Kedokteran Jiwa dan Kesehatan Jiwa, h. 5758.

8 Zakiah Daradjat, Kesehatan Mental, (Jakarta: PT. Toko Gunung Agung, 2001), h. 20.

9 Achmad Mubarok, Psikologi Qur'ani, (Jakarta: Pustaka Firdaus, 2001), cet. I, h. 30.

10 Abdul Aziz, El-Qussy, Pokok-pokok Kesehatan Jiwa/Mental, (Jakarta: Bulan Bintang, 1975), jilid 2, cet. I, h. 128.

130| Jurnal a l-Amin, Volume 3, No 1, 2015 M/1436 H 
Dari pengalaman klinik psikiatri di Amerika Serikat, ditemukan angka sekitar 3\% dari pasien-pasien yang didiagnosa kecemasan adalah tergolong gangguan phobik, sedangkan angka untuk gangguan panik belum didapatkan angka yang pasti.

a. Gangguan Panik

Gangguan panik yang seringkali disebut sebagai serangan panik adalah suatu keadaan seseorang yang mengalami kecemasan dan ketakutan luar biasa. Ini bagaikan teror, seolah yang bersangkutan sedang bergulat dengan maut. Gangguan panik biasanya didahului oleh perasaan ketegangan dan rasa tidak tenang yang berjalan perlahan dan hilang timbul. Namun ketegangan dan ketidaktegangan ini kemudian muncul semakin sering dan semakin memuncak, sampai pada gilirannya muncul sebagai serangan kecemasan yang mendadak.

b. Gangguan Phobik

Phobia adalah ketakutan yang menetap dan tidak rasional terhadap suatu objek, aktivitas atau situasi spesifik, yang menimbulkan suatu keinginan mendesak untuk menghindarinya. Rasa ketakutan ini disadari oleh individu yang bersangkutan bagi suatu yang berlebihan dan tidak masuk akal, namun ia tidak mampu mengatasinya.

Dari sudut psikopatologi disebutkan bahwa reaksi phobia adalah sebagai suatu mekanisme defensif sebagai upaya seseorang untuk mengatasi kecemasannya. Mekanisme defensif tersebut dilakukan dengan jalan mengalihkan kepada ide, objek atau situasi tertentu yang bertindak sebagai simbol dan konflik atau psikotrauma masa lalu. Meskipun yang bersangkutan sadar bahwa sebenarnya tidak ada ide, atau objek tertentu yang membahayakan dirinya (tidak rasional), namun hal itu diciptakan sebagai suatu simbol atas ketidakberdayaan terhadap pengalaman atau psikotrauma masa lalu yang penuh ketegangan dan ketakutan, suatu konflik yang tidak terselesaikan dan ditekan dalam alam tak sadarnya.

\section{B. Terapi Penanggulangan Stres, Depresi dan Kecemasan}


Dalam keyakinan umat Islam bahwa setiap gangguan dan penyakit kejiwaan atau apapun namanya yang menyusahkan kehidupan manusia pasti ada obat dan jalan keluarnya. Firman Allah Swt dalam Qur'an surat Yūnus ayat 67: "Hai manusia, sesungguhnya telah datang kepadamu pelajaran dari Tuhanmu dan penyembuh bagi penyakit penyakit (yang berada) dalam dada dan petunjuk serta rahmat bagi orang-orang yang beriman." Selain itu, Allah juga berfirman dalam Qur'an surat al-Ra'd ayat 28: "(yaitu) orangorang yang beriman dan hati mereka menjadi tenteram dengan mengingat Allah. Ingatlah, hanya dengan mengingat Allahlah hati menjadi tenteram."

Dalam psikiatri dikenal bentuk terapi yang disebut 'Terapi Holistik'. Dalam Terapi Holistik dimaksudkan bentuk terapi yang tidak hanya menggunakan obat dan ditujukan hanya kepada bentuk gangguan jiwanya saja, melainkan juga mencakup aspek lain, sehingga pasien diobati secara menyeluruh baik dari segi organ biologis, psikologis, psikososoial, maupun spiritualnya atau dengan kata lain terapi holistik adalah bentuk terapi yang memandang pasien secara menyeluruh (manusia yang utuh).

Terapi holistik ini sejalan dengan bentuk diagnostik yang dianut psikiatri, yaitu yang disebut diagnosis multiaksial yang meliputi:

Aksis 1: Jenis gangguan jiwa

Aksis 2: Ciri/gangguan kepribadian

Aksis 3: Kelainan fisik (organ)

Aksis 4: Stresor psikososial

Aksis 5: Kemampuan adaptasi.

Apabila kepada pasien dapat ditegakkan kelima aksis tersebut dan kepadanya dapat diberikan terapi masingmasing aksis, maka pasien tersebut telah mendapat terapi holistik. Tujuan terapi holistik adalah tidak saja menghilangkan keluhan-keluhan belaka, namun lebih luas dari pada itu sehingga pasien akan mampu fungsi-fungsi hidupnya sehari-hari.

Menurut Dadang Hawari, dalam hal terapi pada gangguan stres, kecemasan dan depresi dapat diberikan terapi sebagai berikut: (1) psikoterapi psikiatri, (2) psikoterapi keagamaan, (3) psikoparma, (4) terapi somatik, (5) terapi relaksasi, (6) terapi perilaku. Yang ideal adalah 
dengan jalan memberikan bentuk-bentuk terapi tersebut secara bersamaan, berurutan dan tidak terputus. ${ }^{11}$

1. Psikoterapi Psikiatrik

Bentuk terapi ini adalah menganut asas-asas psikiatri yang lazim. Tujuan utama jenis terapi ini adalah untuk memulihkan kepercayaan diri dan memperkuat fungsi ego.

2. Psikoterapi Keagamaan

Memberikan psikoterapi dari sudut keagamaan dapat dianjurkan, mengingat bahwa sebagian besar pasien Indonesia beragama. Dalam agama Islam dapat ditemukan ayat-ayat Qur`an, Hadits yang mengandung tuntunan bagaimana dalam kehidupan di dunia ini manusia bebas dari rasa cemas, tegang, depresi, dan sebagainya. Demikian pula doa-doa yang pada intinya memohon kepada Allah Swt agar dalam kehidupan ini diberi ketenangan, kesejahteraan dan keselamatan baik di dunia maupun di akhirat.

3. Psikofarma

Dari berbagai jenis terapi untuk gangguan afektif, maka terapi psikofarma (psikoformakoterapi) dengan obat anti depresan merupakan pilihan utama, baik pada gangguan bipolar ataupun pada depresi.

4. Terapi Somatik

Yang dimaksudkan dengan terapi di sini adalah memberikan jenis obat-obatan yang ditujukan kepada keluhan/kelainan fisik atau organik pasien. Berbagai keluhan/kelainan tubuh terutama yang didasari oleh sistem saraf otonom dapat muncul sebagai manifestasi kecemasan atau depresi pada mereka yang menderita gangguan panik atau phobik.

5. Terapi Relaksasi

Jenis terapi ini diberikan kepada pasien yang mudah disugesti. Metode ini lazimnya dilakukan oleh terapis yang menggunakan hipnosis. Dengan terapi ini pasien dilatih untuk melakukan relaksasi.

6. Terapi Perilaku

11 Dadang Hawari, Al-Qur'an Ilmu Kedokteran Jiwa dan Kesehatan Jiwa, h. 67.

Jurnal a l-Amin, Volume 3, No 1, 2015 M/1436 H | 133 
Dengan terapi ini dimaksudkan agar pasien berubah baik sikap ataupun perilaku terhadap objek atau situasi yang menakutkan. Prinsip yang dilakukan adalah desensitisasi, agar pasien tidak lagi sensitif terhadap objek tertentu. Secara bertahap pasien dibimbing dan dilatih menghadapi objek yang menimbulkan panik atau phobik.

Latihan ini dilakukan berulang-ulang setahap demi setahap sampai pada akhirnya pasien dapat menghadapinya sendiri tanpa bantuan orang lain. Sudah barang tentu bentuk latihan perilaku ini didahului dengan memberikan psikoterapi untuk memperkuat kepercayaan diri, obat antidepresan dan antiansietas.

Penanggulangan terhadap problem kejiwaan pada prinsipnya dalam perspektif psikolog muslim, adalah problem akhlak yang mulia. Maka penanggulangannya dapat berdampak kepada ketenangan, kebahagiaan, lahir dan batin dunia akhirat serta jiwa yang sehat. ${ }^{12}$

\section{Upaya Meningkatkan Kekebalan Terhadap Stres}

Firman Allah surat al-Baqarah ayat 153: "Hai orangorang yang beriman, jadikanlah sabar dan shalat sebagai penolongmu. Sesungguhnya Allah beserta orang-orang yang sabar."

Tantangan dan perjuangan hidup yang berat dan kompleks, perubahan nilai moral dan etika pada gilirannya dapat mengakibatkan ketegangan stres. Stres adalah bagian dari kehidupan yang tak dapat dihindari, oleh karena itu yang harus dilakukan adalah mengatur hidup agar stres tidak menimbulkan reaksi yang disebut distres, yaitu kepatologian yang disertai keluhan fisik atau psikis.

Beberapa petunjuk untuk meningkatkan kekebalan terhadap berbagai problema kehidupan sehari-hari menurut Dadang Hawari sebagai berikut: ${ }^{13}$

12 Hasan Langgulung, Peralihan Paradigma Dalam Pendidikan Islam dan Sains Sosial, (Jakarta: Gaya Medya Pratama, 2002), h. 165.

13 Dadang Hawari, Al-Qur'an Ilmu Kedokteran Jiwa dan Kesehatan Jiwa, h. 7982.

134| Jurnal a l-Amin, Volume 3, No 1, 2015 M/1436 H 
1. Makanan; makanlah secara teratur, usahakan jangan sampai terlambat. Makanan dingin dan monoton dapat menurunkan daya tahan.

2. Tidur; tidur obat alamiah yang dapat memulihkan keletihan fisik dan mental. Atur jadwal tidur anda secara teratur. Usahakan tidur 78 jam semalam. Paling tidak empat malam dalam seminggu harus dapat tidur rata-rata 78 jam semalam. Usahakan jangan sampai bangun tidur sesudah matahari terbit. Bangunlah sebelum siang kirakira jam 5 pagi diikuti olah raga. Tetapi menurut penulis tentu terlebih dahulu melaksanakan shalat bagi umat Islam.

3. Olah raga; tidak perlu yang mahal-mahal, bahkan tanpa biaya sekalipun, misalnya lari-lari pagi, jalan-jalan pagi atau senam dan lain-lain. Usahakan dua kali seminggu gerak badan hingga berkeringat, bila selesai mandi dengan air hangat.

4. Rokok; yang terbaik tidak merokok. Kalau merokok jangan lebih dari 10 batang sehari. Bila merokok lebih banyak maka daya tahan atau kekebalan anda terhadap stres akan jauh merosot, dan berisiko tinggi mengalami kanker paru-paru dan penyakit jantung koroner.

5. Minuman keras; tidak peduli berapa kadar alkohol yang dikandungnya. Alkohol dapat mempengaruhi daya pikir dan emosi, bahkan gangguan kronis pada lever.

6. Agama; dalam memeluk suatu agama, hendaknya tidak saja secara formal memeluknya, tetapi hendaknya menghayati dan mengamalkannya, sehingga terasa pengaruh kekuatan dan ketenangan. Usahakan setiap hari dapat menyempatkan waktu untuk mencari ketenangan dari shalat, atau berdoa memohon ampunan dan petunjuk Allah Swt.

\section{Kesimpulan}

Uraian di atas dapat disimpulkan bahwa stress, depresi, dan kecemasan adalah reaksi tubuh terhadap setiap tuntutan atasnya. Dalam kehidupan ini, berbagai permasalahan yang pelik, kompleks, saling tumpang tindih adalah hal yang lumrah dan alami yang terkadang mustahil dapat dihindari, yang terpenting sebenarnya bukan menghindari permasalahan, atau tantangan tetapi adalah mencari pemecahannya. 
Namun terkadang tidak semua orang mampu menemukan jalan keluar dari permasalahannya, seperti gangguan stres, depresi dan kecemasan, karenanya perlu dibantu oleh yang ahli. Dalam pandangan Islam setiap penyakit pasti ada obatnya tidak terkecuali stres dan sebagainya. Bila setiap muslim mau menjalankan agama dengan baik dan benar sesuai dengan tuntunan al-Qur'an dan al-Sunnah, sehingga akan terhindar dari gangguan dan penyakit kejiwaan.

\section{E. Saran-Saran}

Hendaklah penyakit-penyakit ini dihindari dan ditangani secara serius dengan mendirikan lembaga-lembaga formal dan informal dalam rangka menjadikan manusia terhindar darinya. Begitu pula para psikiater dan psikolog semakin meningkatkan kerjanya di tengah masyarakat, dimana masyarakat di era sekarang ini sudah banyak yang kehilangan jati dirinya. 


\section{DAFTAR PUSTAKA}

Abdul Aziz, El-Qussy, Pokok-pokok Kesehatan Jiwa/Mental, Jakarta: Bulan Bintang, 1975, jilid 2, cet. I.

Achmad Mubarok, Psikologi Qur'ani, Jakarta: Pustaka Firdaus, 2001, cet. I.

Dadang Hawari, Al-Qur'an Ilmu Kedokteran Jiwa dan Kesehatan Jiwa, Jakarta: PT. Dana Bakti Primayasa, 1996.

Departemen Pendidikan dan Kebudayaan RI; Kamus Besar Bahasa Indonesia, Jakarta: Balai Pustaka, t.th., cet. II.

Hasan Langgulung, Peralihan Paradigma Dalam Pendidikan Islam dan Sains Sosial, Jakarta: Gaya Medya Pratama, 2002.

Hasan Usman, Metode Penelitian Sejarah, Jakarta: Departemen Agama, 1986.

John Echols dan Hassan Syadily, Kamus Inggris-Indonesia, Jakarta: PT. Gramedia, 1976, cet. XIX.

Musthafa Fahmi, Kesehatan Jiwa Dalam Keluarga Sekolah dan Masyarakat, alih bahasa oleh Zakiah Daradjat Jakarta: Bulan Bintang, 1977, Jilid 3.

Tim Penyusun Ensiklopedia, Ensiklopedia Nasional Indonesia, Jakarta: PT. Cipta Abadi, 1984, cet. II, Jilid II.

Zakiah Daradjat, Kesehatan Mental, Jakarta: PT. Toko Gunung Agung, 2001. 
SEBAB DAN AKIBAT STRES, DEPRESI DAN KECEMASAN SERTA PENANGGULANGANNYA

138| Jurnal a 1-Amin, Volume 3, No 1, 2015 M/1436 H 